\title{
THE INFLUENCE OF REGIONAL DEVELOPMENT FUNDING RESOURCES ON REGIONAL ECONOMIC GROWTH IN THE REGENCY OF LANNY JAYA IN PAPUA
}

\author{
Apolo Safanpo, Arung Lamba \\ Faculty of Engineering, University of Cenderawasih, Jayapura, Papua, Indonesia \\ E-mail: pr.arung.lamba@gmail.com
}

\begin{abstract}
The objective of this research is to analyze and measure the influence of development funding resource on economic growth in primary, secondary and tertiary sectors in the regency of Lanny Jaya. This study uses descriptive analysis and multiple linear regression analysis. The results of this study show that the influence of development funding resource on the economic growth of primary sector in the regency of Lanny is as follows: simultaneously does not have any influence; partially, from the four funding resources, only general allocation fund influences the economic growth of primary sector in the regency of Lanny Jaya; this indicates that the government of Lanny Jaya do not contribute much and their effort in managing business in primary sector such as agriculture, plantation, fishery, and mining, is not optimal, so they still do the business independently and traditionally.
\end{abstract}

\section{KEYWORD:}

Developmental, funds, economic growth, regency, business.

General definition widely used to refer regional development planning has been presented by experts (e.g. (Raharjo Adisamita, 2010; Poernomosidi Hadjisaroso, 2001; and Robinson Tarigan, 2010). In general, they stated that regional development planning is a series of planning materialized into policies in various sectors aimed at increasing people's living standard, improving work opportunity, enhancing economic growth, creating equitable development, and sectoring shifts of economic activity processes from primary to secondary and tertiary sector.

In its application, development is not only conducted by developing countries; developed countries also do the same. However, significant differences are present in the development carried out in both groups because problems in both groups are different. The problem in developing countries is that they are still trying to make their people able to survive. If this problem is settled, the next thing is building economic foundation in order to compete in national market. The problem of developed countries is sustainable expansion to support its well-established economy in order to reach welfare desired by all of their people.

Lanny Jaya is regency separated from Jayawijaya regency in 2008 located in the mountainous area of Papua province. As new regency, Lanny Jaya is still poor in facilities. Its geographical location that is far from provincial government, not to mention from national government, makes this regency is only accessible using small airplanes. This makes the economy of this region is very far behind older regions. Therefore, cost in this regency is very high, making its all economic subsectors unproductive, which leads to difficulties in increasing its people's income and reducing the number of poor people.

This phenomenon is an irony since this regency is rich with natural resource potentials. Although a small part of its people has enjoyed its natural richness, quite high income, and luxurious life, the bigger portion of its population still live under the poverty standard. This shows an inequitable economic condition. The gap between the rich and the poor in this regency is still high.

The natural process above can be achieved if the existing development assumptions; participation in full potential usage, equal personal capability, and rational conduct of all actors, are fulfilled. However, those assumptions are frequently not facilitated in the existing natural process, leading to new problems in development, e.g. unemployment, poverty, and inequitable development that causes social gap in the society. 
Funding resources of development have been received by regional governments after the autonomic regime; they are own source revenue (PAD), general allocation fund (DAU), special allocation fund (DAK), and revenue sharing fund (DBH). PAD is a funding resource that reflects the capability of a region in financing the development in its area. This means that higher capability of regional government in financing its development will improve the ability of the region to finance its developmental expenditures. DAU, DAK, and DBH are transferred funds from the central government to local government, the balancing fund between central and local government in autonomic era.

Research Objective:

- to analyze and measure the influence of development funding resources on the economic growth of primary sector in the regency of Lanny Jaya,

- to analyze and measure the influence of development funding resources on the economic growth of secondary sector in the regency of Lanny Jaya,

- to analyze and measure the influence of development funding resources on the economic growth of tertiary sector in the regency of Lanny Jaya.

\section{LITERATURE REVIEW}

Growth Theory. In understanding economic growth theory, the grand theory of this study is endogenous growth of Robert Solow and Dernburg Thomas, which will be enriched with various theories from other experts.

In his book, Dernburg Thomas (2005) mentioned that Robert Solow had developed his theory about endogenous economic growth in the late 1982 and early 1990. This theory is centered on accumulation of capital and its relation with saving. This analysis starts by an assumption that technological process does not occur in economic growth process. Therefore, the economy will reach long-term level from output and capital, which is commonly called as the steady state.

The state occurs in a condition where combination between per capita Gross Domestic Product (GDP) and per capita capital makes the economy remains in that position.

Concept of Development Based on Sector. This study refers to the definition that economic development is a continuous process toward changes in various sectors to increase per capita income, and the per capita increase must sustain for a long term accompanied with improvement in institution system in economy, social, politics, law, and culture. The definition of sectoral growth is elaborated in several books (i.e. Ahmad Sujana 2015, Raharjo Adisamita, 2001, 2007; Budiono, 1999; Suwarno, 2006), suggesting that sectoral growth is changes in various sector to a better condition. Thus, growth is frequently used as an indicator of development in certain region or area. Suwarno (2006) and Raharjo Adisamita (2001) stated that the development process in those sectors is divided into three groups as follows:

1. Primary sector is a sector that does not process raw material. Instead, it utilizes natural resource potentials such as soil and anything contained in it. This sector consists of agriculture, plantation, fishery, forestry, and mining, as well as other sectors that use natural resources.

2. Secondary sector is a sector that processes raw material either from primary or secondary business field into other goods with higher value. This sector consists of manufacturing industry, electricity, gas and water, waste, recycling, and construction.

3. Tertiary sector is a sector whose production is not in physical form but service instead. This sector consists of trade, car and motorcycle repairmen, transportation, warehousing, accommodation and catering, information and communication, finance and insurance, real estate, company service, governmental administration service, education service, health and social service, etc.

Similar to the definition according to the government of the regency of Lanny Jaya (BPPD Lanny Jaya, 2014), the sectors are defined and divided as follows. 
4. Primary sector is a business field that does not process raw material. Instead, it utilizes natural resource potentials such as soil and anything contained in it. This business field consists of agriculture, plantation, fishery, forestry, and mining.

5. Secondary sector is a business field that processes raw material either from primary or secondary business field into other goods with higher value. This business field consists of manufacturing industry, electricity, gas and water, waste, recycling, and construction

6. Tertiary sector is a business field whose production is not in physical form but service instead. This business field consists of trade, car and motorcycle repairmen, transportation, warehousing, accommodation and catering, information and communication, finance and insurance, real estate, company service, governmental administration service, education service, health and social service, etc.

Concept of Development Funding Resource Usage. Laws regarding local autonomy and laws regarding special autonomy for Papua (Republik Indonesia, 2001) make the fund transfer system from the central government to Papua change significantly, since they enable regional governments to have the authority to exploit the potential of their regions to improve their financial capability.

According to Law number 25 of 2004, there are three fund transfers, or balancing funds; they are 1. Revenue Sharing Fund (DBH), General allocation fund (DAU), and Special allocation fund (DAK).

Other than those three types of balancing fund, another transfer is stipulated in Laws number 21 of 2001, which is Special Autonomy Fund. The law is expected to accelerate economic growth in sub national regions, especially those with good economic potentials. However, less potential regions can still develop themselves using balancing fund in forms of general allocation fund (DAU) and special allocation fund (DAK).

All parties involved in the formulation of Law number 21 of 2001 and number 25 of 2004 expected that the regulation will help all regions with high natural resource yet low in economy catch up their lag (Abigael Sundoyo, 2006).

Similar thoughts were also presented by Tri Sungkono (2010), who mentioned that the balancing funds (DBH, DAU, and DAK), together with own-source revenue (PAD), are beneficial as new strengths for a region, especially those that are still left behind, to develop their regions and to catch up their lag.

Concept of Relationship between Central Finance and Regional Finance. The constitution of Indonesia has mandated an extensive autonomy in the frame of the Unitary State of the Republic of Indonesia. Therefore, a fair and harmonious arrangement regarding financial relation, public service, the use of natural resource and other resources between central government and local government is needed. The arrangement will support the implementation of regional autonomy through the provision of funding resources based on the authority of central government, decentralization, deconcentration, and assistance task. Fiscal balance between central and local government is in form of financial system arranged based on a clear division of authority, task, responsibility among governmental levels.

The interaction between central and local government is carried out according to fiscal balance principle as stipulated in Law number 33 of 2004. The fiscal balance between central and local government is a fair, proportional, democratic, transparent, and efficient system of fiscal division. It is conducted to establish funding for decentralization implementation by considering the potential, condition, and the need of regions, as well as the amount of funding for deconcentration and assistance task.

Fiscal balance between central and local government is a state's financial subsystem as a consequence of task division between the two. The balance is a part of an inseparable arrangement of the state's financial system, which is meant to regulate funding system over government's authority that is handed to, delegated to, and assisted by local governments. The distribution of the state's financial resource to local governments is to implement decentralization based on task delegation from central government to local government by 
considering the stability of national economic condition and fiscal balance between central and local government.

The fiscal relationship between central and local government for regional autonomy is established by giving freedom to local governments to carry out governmental tasks. Regulation number 33 of 2004 has set financing foundation of local governments as follows. According to paragraph 4, the accomplishment of local governments' task regarding the implementation of decentralization is financed using the national budget (APBN).

The accomplishment of governmental tasks carried out by governors regarding the implementation of deconcentration is financed using the national budget. The Effectuation of governmental tasks carried out by governors regarding assistance task is financed using the national budget. The delegation of authority regarding the implementation of deconcentration and/or task assignment regarding the accomplishment of assistance task from central to local government is accompanied with fund transfer, which amount is based on the load of the authority delegated to and/or the tasks requested to be accomplished by the local government.

The acceptance of local government in establishing decentralization consists of local revenue and financing. Yani Ahmad (2006) mentioned in his book that local income sources have their own objectives as follows:

1. Own-source revenue (PAD) aims to provide authority to local government to finance the regional autonomy according to the potentials of the regions as the realization of decentralization.

2. Balancing fund (DBH, DAU, and DAK) aims to reduce fiscal gap between central and local government and among local governments.

3. Other revenues that enable local government to receive revenues, other than those from own-source revenue, balancing fund, and local government loan.

The sources of funding are:

1. Local budget surplus

2. Local government loan

3. Local government's reserve fund

4. Result of separated sales of local asset

Own-source revenue (PAD) comes from local tax, local retribution, result of separated management of local asset, and other legal own-source revenue and aims to provide freedom to local governments to find and use resources to finance regional autonomy as the materialization of decentralization principle. The revenue is acquired by local government, levied based on local government regulation according to provisions of laws, and used for public interest.

Concept of Gross Regional Domestic Product (GRDP). In carrying out economic planning, states or regions certainly need various statistical data to determine the strategies and policies, so development targets can be met. This confirms the opinion of Djoyohadikusumo S (1999), who stated that the strategies and policies of economic development taken in previous times must be monitored and evaluated, so quantitative description about the condition in the past and present, as well as targets to be achieved in the future, could be measured clearly and definitively.

Djoyohadikusumo S (1999) also stated that, in its essence, economic development is a series of sectors and policies aiming at increasing people's living standard, expanding employment, equalizing people's income, increasing regional economic relationship, and sectoring shifts of economic activities from primary to secondary and tertiary sectors. In other words, the direction of economic development is sectoring so that people's income increases significantly and is distributed equitably.

Raharjo Adisamita (1996), in his book about practical guidelines for calculating Gross Regional Domestic Product (GRDP) of regencies and cities, explained that the three approaches that can be used to calculate national or regional income are:

1. Production Approach,

2. Income Approach, and

3. Expenditure Approach. 
Concept about Local Revenue. The concept of own-source revenue can be interpreted as local revenue that depends on the general economic condition and potential of the income source of a particular region. This is supported by Soekarwo (2003), who asserted that ownsource revenue (PAD) is revenue that reflects the ability of a region to compile funding resources to finance the activity of concerned region. Therefore, it can be concluded that own-source revenue is regular revenue from sectors of local government in using various financial source potentials to finance the government's tasks and responsibilities.

According to paragraph 6 of Law number 32 of 2004, own-source revenue comes from:

1. Local tax,

2. Local retribution,

3. Sectorization of local assets and separated result of local resource management,

4. Acceptance from service and other legal local income.

Mardiasmo (2000) defined local tax as tax levied by local government based on the tax regulation set by the local government to finance the activity of the region. According to Law number 34 of 2000 regarding local tax, tax is a routine contribution from individuals or organizations to local government not followed by equal direct compensations enforced based on applicable legal provisions used to finance local government and local development.

There are boundaries regarding tax presented by experts. However, the principle is similar in that tax is a payment that can be forced from citizens to the government without from which directly appointed compensation is provided (Suparmoko M, 2006). Based on the definitions above, it can be concluded that elements of tax are:

1. Public payment to government,

2. Based on laws,

3. Not followed by direct compensation,

4. Used for financing government's expenditures.

\section{RESEARCH FRAME AND HYPOTHESIS}

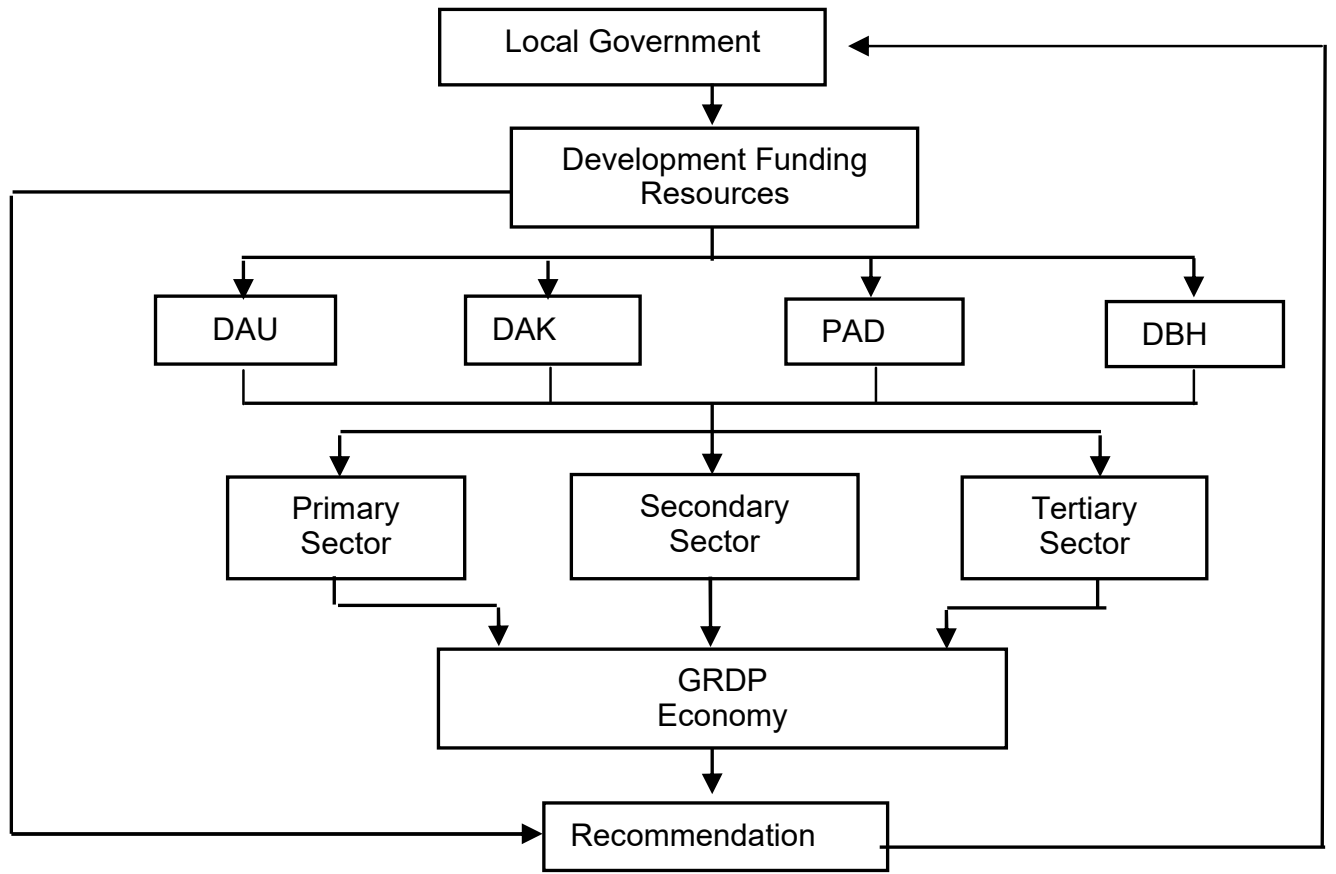

Source: Researcher's Conceptual Framework, 2017.

Hypothesis:

1a. There is a simultaneous influence of development funding resources (PAD, DBH, $\mathrm{DAU}$, and DAK) on the economic growth of primary sector. 
$1 \mathrm{~b}$. There is a partial influence of development funding resource $(P A D, D B H, D A U$, and DAK) on the economic growth of primary sector.

$2 a$. There is a simultaneous influence of development funding resources (PAD, DBH, $\mathrm{DAU}$, and DAK) on the economic growth of secondary sector.

$2 \mathrm{~b}$. There is a partial influence of development funding resource (PAD, DBH, DAU, and DAK) on the economic growth of secondary sector.

3a. There is a simultaneous influence of development funding resources (PAD, DBH, $\mathrm{DAU}$, and DAK) on the economic growth of tertiary sector.

$3 \mathrm{~b}$. There is a partial influence of development funding resource $(P A D, D B H, D A U$, and DAK) on the economic growth of tertiary sector.

\section{METHODS OF RESEARCH}

The location of this study is the regency of Lanny Jaya, based on the consideration that this regency was established not long time ago, so the researcher is interested to see the influence of development funding resources on the economic growth of all sectors

This research uses descriptive analysis and multiple linear regression analysis. In its analysis, sectoral GRDP is treated as the dependent variable, and development funding resources are treated as the independent variables. The sectoral GRDP used in this study is divided into three; primary, secondary, and tertiary. Thus, there will be three stages of multiple regression model of:

$$
Y_{i}=\beta_{0}+\beta_{1} X_{1}+\beta_{2} X_{2}+\beta_{3} X_{3}+\beta_{4} X_{4}+\varepsilon
$$

Where: $Y_{i}=$ Amount of GRDP of each sector (primary, secondary, and tertiary); $X_{1}=$ Ownsource revenue (PAD); $X_{2}=$ Revenue Sharing Fund $(\mathrm{DBH}) ; X_{3}=$ General Allocation Fund $(\mathrm{DAU}) ; X_{4}=$ Special Allocation Fund (DAK); $\varepsilon=$ Error.

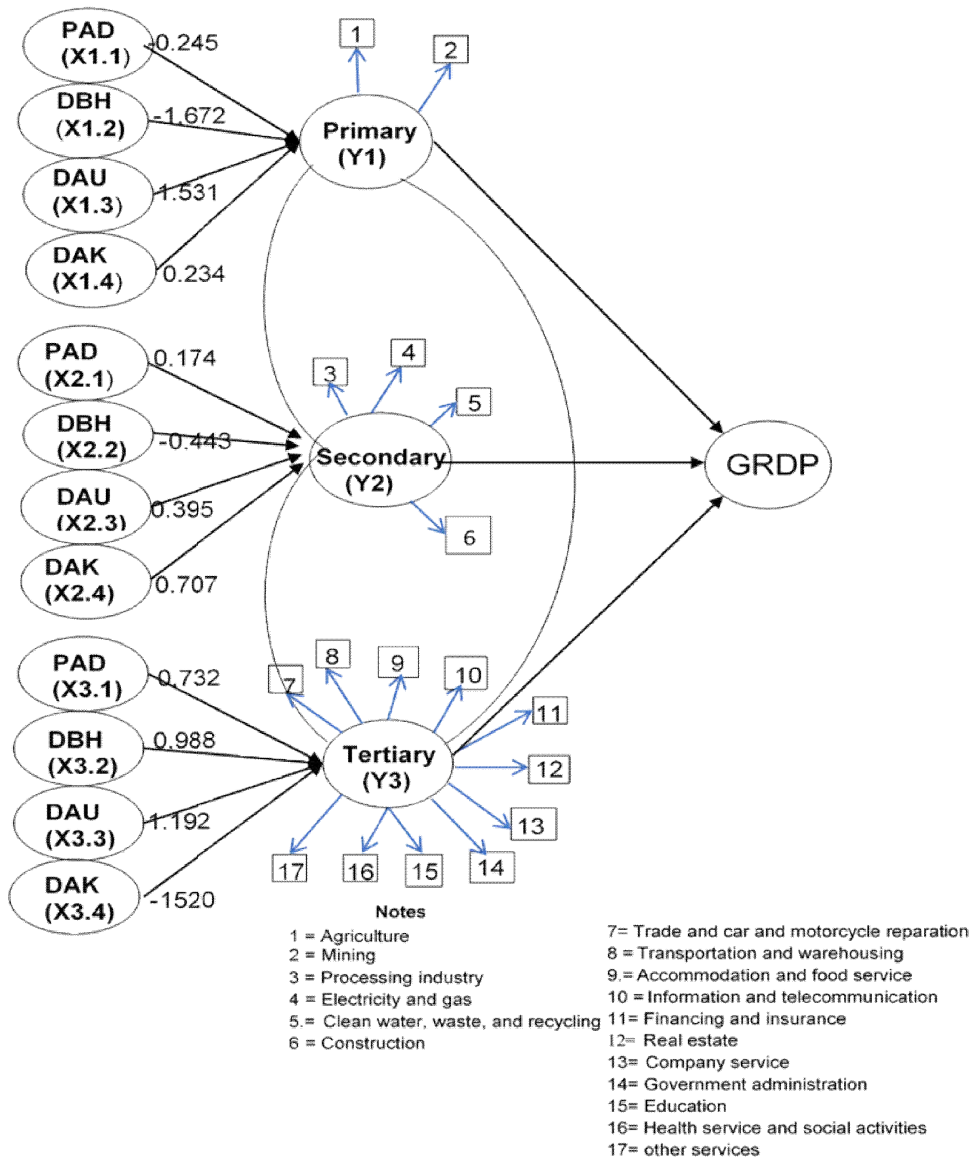


Analysis on the Influence of Development Funding Resources (PAD, DBH, DAU, and $D A K)$ on the Economy of Primary Sector. To identify the simultaneous influence of PAD, $\mathrm{DBH}, \mathrm{DAU}$, and DAK on the GRDP of primary sector in the regency of Lanny Jaya and to determine funding resource that has a dominant influence on the economy of primary sector in the regency, a model should be selected first. The objectives of this selection are to calculate the simultaneous influence of independent variables (PAD, DBH, DAU, and DAK) and to determine independent variable that has a dominant influence on the dependent variable, which, in this case, is the GRDP of primary sector in Lanny Jaya. Therefore, the first step is including all independent variables in the regression model, and the model is analyzed.

To identify the variable, of PAD, DBH, DAU, and DAK, that has the strongest influence on GRDP, this study uses Backward Elimination Method in selecting the model. The purpose of this step is to determine variables significant in influencing the economy of primary sector.

Variables that are insignificant based on the first step of multiple linear regression, which can be determined from the obtained regression coefficient, will be excluded from the model, so the best model to identify variable with the strongest influence is obtained.

Therefore, it can be said that the result of Backward Elimination Method can be used to identify two issues; they are:

1. the simultaneous influence of the four funding resources on the Gross Regional Domestic Product (GRDP) of all sectors (primary, secondary, and tertiary sector) in the regency of Lanny Jaya in the period of 2008-2015, and

2. The variable that has the strongest influence on the Gross Regional Domestic Product (GRDP) of all sectors (primary, secondary, and tertiary) in the regency of Lanny Jaya in the period of 2008-2015.

Two answer the two aforementioned enquiries, four steps of multiple linear regression analysis is conducted using SPSS. The result is as follows.

Table 1 - Result of $F$ test and $t$ test for primary sector

\begin{tabular}{|c|c|c|c|c|c|c|}
\hline \multirow{2}{*}{ Model } & \multicolumn{2}{|c|}{ Goodness of Fit test } & \multirow{2}{*}{ Funding Resources } & \multirow{2}{*}{ Coefficients } & \multicolumn{2}{|c|}{ Partial test } \\
\hline & $\mathrm{F}$ & Sig & & & $\mathrm{t}$ & Sig \\
\hline \multirow{5}{*}{1} & \multirow{5}{*}{4.148} & \multirow{5}{*}{0.136} & (Constant) & 422.972 & 1.384 & 0.260 \\
\hline & & & PAD & -0.245 & -0.056 & 0.959 \\
\hline & & & DBH & -1.672 & -0.176 & 0.871 \\
\hline & & & DAU & 1.531 & 1.766 & 0.176 \\
\hline & & & DAK & 0.234 & 0.089 & 0.935 \\
\hline \multirow{4}{*}{2} & \multirow{4}{*}{7.364} & \multirow{4}{*}{0.042} & (Constant) & 424.398 & 1.608 & 0.183 \\
\hline & & & DBH & -1.856 & -0.241 & 0.822 \\
\hline & & & DAU & -1.530 & 2.037 & 0.111 \\
\hline & & & DAK & 0.234 & 0.112 & 0.916 \\
\hline \multirow{3}{*}{3} & \multirow{3}{*}{13.757} & \multirow{3}{*}{0.009} & (Constant) & 440.569 & 2.224 & 0.077 \\
\hline & & & DBH & -2.124 & -0.324 & 0.759 \\
\hline & & & DAU & 1.559 & 2.470 & 0.057 \\
\hline \multirow{2}{*}{4} & \multirow{2}{*}{32.215} & \multirow{2}{*}{0.001} & (Constant) & 383.471 & 4.608 & 0.004 \\
\hline & & & DAU & 1.373 & 5.676 & 0.001 \\
\hline
\end{tabular}

Result: Data processing in SPSS 13.

- First Step:

Because the objective of this step is to determine how development funding resource simultaneously influences the GRDP of primary sector, the four funding resources are included in the model. The regression model is as follows.

$$
\mathrm{Y} 1.1=422.972-0,245 \mathrm{PAD}-1.672 \mathrm{DBH}+1.531 \mathrm{DAU}+0,234 \mathrm{DAK}
$$

Using the equation above, the obtained constant value is 0.41 , which informs that in the absence of development funding resource from PAD, DBH, DAU, and DAK, the GRDP of primary sector is still in the position of 422.972 , or IDR $422,972,000,000$. To determine 
whether the model is appropriate for forecasting the GRDP of primary sector, Goodness od Fit test should be conducted. This test uses $F$ test with hypothesis formulation as follows.

Ho: development funding resources (PAD, DBH, DAU, and DAK) do not influence the economy of primary sector.

$\mathrm{Ha}$ : there is, at least, one development funding resource (among PAD, DBH, DAU, and DAK) that influences the economy of primary sector.

Based on the SPSS output in the table above, the $F$ value is 4.148 with the model significance value of 0.136 . Therefore, this value is greater than the significance level in use ( $\alpha=5 \%$ ), so the null hypothesis is accepted.

The conclusion from the explanation is that the four variables of development funding resources do not influence the economy of primary sector. Thus, the next model needs to be found by excluding independent variable that has the least significance to the model. The most insignificant variable is identified by conducting parameter test partially. The test that is conducted is $t$ test with the hypothesis formulation as follows:

$$
\begin{aligned}
& H 0: \beta i=0 \\
& H a: \beta i=0
\end{aligned}
$$

The result of parameter test conducted partially suggest that the significant value of all development funding resource variables is greater than the predetermined significance level $(\alpha=5 \%)$. Therefore, it can be concluded that there is no relationship between development funding resource and the economy of primary sector, so one independent variable with the highest significance, which is PAD with the significance level of 0.959 (see table above), needs to be excluded.

- Second step:

In this second step, analysis is performed by including three development finding resource variables; they are $D B H, D A U$, and DAK. PAD is excluded from the model because it has the highest significance level $(0.959)$ in the t test above. follows:

The regression model using three development funding resource variables is as

$$
\mathrm{Y} 1.2=424.398-1.856 \mathrm{DBH}+1.530 \mathrm{DAU}+0,234 \mathrm{DAK}
$$

Based on the $F$ test in the table above, the model produces $F$ value of 7.364 at the significance level of 0.042 . Because this value is greater than the predetermined significance level (two-way test $\alpha / 2=2.5 \%$ ), null hypothesis is accepted, which means that model with three development funding resource variables is not significant.

The least significant variable in this second step is DAK, marked by significance value of 0.916 in $t$ test, so third step is needed, which is by excluding DAK from the model.

- Third Step:

The third step is a regression model using two development funding resource variables; they are $\mathrm{DBH}$ and DAU, since DAK is excluded from the model because of its insignificance. This third model is written mathematically as follows.

$$
\mathrm{Y} 13=440.569-2.124 \mathrm{DBH}+1.559 \mathrm{DAU}
$$

This model results in the statistic $F$ value of 13.757 with the significance value of 0.009 , which means that null hypothesis is rejected, or there is a parameter of development funding resource that does not equal to zero $($ sig $<0)$. In other words, development funding resources, i.e. DBH and DAU, simultaneously influence the economy of primary sector in the regency of Lanny Jaya.

In addition, to identify which variable, between $\mathrm{DBH}$ and $\mathrm{DAU}$, that is most significant in influencing the economy of primary sector in the regency of Lanny Jaya, partial-wise parameter test ( $t$ test) is conducted. Based on the $t$ test result, DBH is not significant, so this variable is excluded from the model. 
- Fourth Step:

This model is the final step and produces the strongest variable that influences the economy of primary sector in the regency of Lanny Jaya.

Using Backward Elimination Method and DAU as the variable that influences the economy of primary sector, this model produces coefficient of determination $\left(R^{2}\right)$ of 0.843 . This coefficient of determination value can explain variations of primary sector GRDP at $84.3 \%$. The remaining $15.7 \%$ is influenced other variables not included in this fourth model, e.g. DBH, DAK, and PAD. The fourth model can be written mathematically as follows:

$$
\mathrm{Y} 14=383.471+1.373 \mathrm{DAU}
$$

By observing the regression equation above, two information can be obtained; they are:

1. The constant value of 383.471 in the model above suggests that, if general allocation fund equals to zero (not available), the Gross Regional Domestic Product (GRDP) of primary sector in the regency of Lanny Jaya is only IDR 383,471,000,000.

2. The coefficient value of 1.373 in the model above indicates that, if the value of General Allocation Fund (DAU) increases for IDR 1,000,000,000 (one billion rupiahs), the economy in primary sector will increase for IDR 1,373,000,000.

Based on the analysis on the influence of development funding resources on the economy of primary sector, it can be concluded that, of four funding resources that are analyzed, i.e. PAD, DBH, DAU, and DAK, in the regency of Lanny Jaya, only DAU that influences the economy in primary sector. This is possible because, of four existing funding resources, DAU is indeed the biggest. The magnitude of influence from General Allocation Fund (DAU) in the economy of Lanny Jaya indicates that the dependency of this regency on central government is still very high.

Analysis on the Influence of Development Funding Resources (PAD, DBH, DAU, and $D A K)$ on the Economy of Secondary Sector. Similar to the analysis process of primary sector that has previously been conducted, to identify the simultaneous influence of PAD, DBH, DAU, and DAK on the GRDP of secondary sector in the regency of Lanny Jaya and to determine funding resource that has a dominant influence on the economy of secondary sector in the regency, a model should be selected first. The objectives of this selection are to calculate the simultaneous influence of independent variables (PAD, DBH, DAU, and DAK) and to determine independent variable that has a dominant influence on the dependent variable, which, in this case, is secondary sector.

Three-step regression analysis model using SPSS is conducted, from which the result is as follows:

Table 2 - Result of F test and $\mathrm{t}$ Test for Secondary Sector

\begin{tabular}{|c|c|c|c|c|c|c|}
\hline \multirow{2}{*}{ Model } & \multicolumn{2}{|c|}{ Goodness of Fit test } & \multirow{2}{*}{ Funding Resources } & \multirow{2}{*}{ Coefficients } & \multicolumn{2}{c|}{ Partial Test } \\
& $\mathrm{F}$ & Sig & & $\mathrm{t}$ & Sig \\
\hline \multirow{4}{*}{1} & & & (Constant) & -0.421 & -0.014 & 0.990 \\
& \multirow{3}{*}{33.595} & \multirow{2}{*}{0.08} & PAD & 0.174 & 0.393 & 0.721 \\
& & & DBH & -0.443 & -0.462 & 0.676 \\
& & DAU & 0.395 & 4.497 & 0.021 \\
& & DAK & 0.707 & 2.626 & 0.077 \\
\hline \multirow{3}{*}{2} & \multirow{3}{*}{56.738} & \multirow{2}{*}{0.001} & (Constant) & -1.434 & -0.052 & 0.961 \\
& & & DBH & -1.313 & -0.391 & 0.716 \\
& & DAU & 0.396 & 5.077 & 0.007 \\
& & DAK & 0.707 & 2.947 & 0.042 \\
\hline \multirow{3}{*}{3} & \multirow{2}{*}{102.369} & \multirow{2}{*}{0.000} & (Constant) & -10.848 & -0.910 & 0.404 \\
& & DAU & 0.368 & -13.103 & 0.000 \\
& & DAK & 0.721 & 3.542 & 0.170 \\
\hline
\end{tabular}

Data processing in SPSS 13.

- First Step: 
Because the objective of this regression analysis step is to determine how development funding resource simultaneously influences the GRDP of primary sector, the four funding resources (PAD, DBH, DAU, and DAK) are included in the model. Therefore, the developed regression model is appropriate with the output of the table above. The result of $F$ test and $t$ test for secondary sector is as follows:

$$
Y 2.1=-0.421+0,174 \mathrm{PAD}-0,443 \mathrm{DBH}+0,395 \mathrm{DAU}+0,707 \mathrm{DAK}
$$

Through the equation above, the constant is minus 0.41 , which informs that in the absence of development funding resource from PAD, DBH, DAU, and DAK, the GRDP of secondary sector in Lanny Jaya will be in negative position $(-0.421)$, or minus IDR $421,000,000,000$.

Based on the goodness of fit test above, the significance value is 0.008 . This value is smaller than the predetermined significance level, so it can be concluded that, in this model, development funding resource from PAD, DBH, DAU, and DAK simultaneously influence the GRDP of secondary sector in the regency of Lanny Jaya. However, after a partial-wise parameter test ( $t$ test) is conducted (see Table 5.13 above), PAD and DBH are not significant because the sig values of their partial test are, respectively, 0.721 and 0.676 , which is greater than their $\mathrm{t}$ values, which are, respectively, 0.393 and -0.462 . However, DAU and DAK are significant because the values of their partial test are, respectively, 0.021 and 0.077 , which is smaller than their $t$ values, which are, respectively, 4.497 and 2.626.

Of the two insignificant variables, PAD is the least significant because it has the highest significance value, which is 0.721 . Therefore, PAD must be excluded from the model of the next step.

- Second Step:

After excluding Own-Source Revenue (PAD) variable from the model, the regression equation in this second step becomes as follows:

$$
\mathrm{Y} 2.2=-1.434-0,313 \mathrm{DBH}+0,396 \mathrm{DAU}+0,692 \mathrm{DAK}
$$

Through the second step regression equation above, the constant is negative, i.e. 1.434. which informs that in the absence of development funding resource from DBH, DAU, and DAK, the GRDP in the regency of Lanny Jaya in secondary sector will be in negative position (-1.434), or minus IDR 1,434,000,000.

Referring to the result of goodness of fit test in the table above, the obtained significance value is 0.001 . this value is smaller than the predetermined significance level $(\alpha=$ $5 \%)$. Therefore, it can be concluded that, in this model, development funding resource from $\mathrm{DBH}, \mathrm{DAU}$, and DAK simultaneously influence the GRDP of secondary sector in the regency of Lanny Jaya.

However, after a partial-wise parameter test (t test) is conducted, DBH is not significant because the sig value of its partial test is 0.716 , which is greater than its $t$ value, which is 0.391 . However, DAU and DAK are significant because the values of their partial test are, respectively, 0.007 and 0.042 , which are smaller than their $t$ values (respectively 5.077 and 2.947).

Because Revenue Sharing Fund $(\mathrm{DBH})$ variable is not significant, it must be excluded from the next step model.

- Third Step:

After excluding Revenue Sharing Fund (DBH) variable from the model, the regression equation in this third step can be mathematically written as follows.

$$
Y 2.3=-10.848-0,368 \text { DAU + 0,721 DAK }
$$

Based on the third step regression equation above, the constant is negative, i.e. 10.848. which informs that in the absence of development funding resource from DAU, and 
DAK, the GRDP in the regency of Lanny Jaya in secondary sector will be in negative position $(-10.848)$, or minus IDR 10,848,000,000.

This third step regression model is the best model, which is using independent variable of DAU and DAK in the model.

Based on the goodness of fit test ( $F$ test) and partial-wise parameter test ( $t$ test) above, it is identified that DAU and DAK variables simultaneously and partially influence the GRDP of secondary sector in the regency of Lanny Jaya.

However, because the significance level on the constant value in the third model is not significant, marked by the sig value of $=0,404>\alpha=5 \%$, the best model is the model that does not include constant in the equation model.

After conducting data reprocessing to obtain the best model without constant, the following result is obtained.

Table 3 - Result of F Test and t Test for Secondary Sector without Constant

\begin{tabular}{|c|c|c|c|c|c|c|c|}
\hline \multirow{2}{*}{ Model } & \multicolumn{2}{|c|}{ Goodness of Fit test } & \multirow{2}{*}{ R-sqr } & \multirow{2}{*}{ Funding resource } & \multirow{2}{*}{ Coefficients } & \multicolumn{2}{|c|}{ Partial test } \\
\hline & $\mathrm{F}$ & Sig & & & & $t$ & Sig \\
\hline 1 & 33.595 & 0,08 & 0.997 & $\begin{array}{l}\text { DAU } \\
\text { DAK }\end{array}$ & $\begin{array}{l}0.353 \\
0.609\end{array}$ & $\begin{array}{c}15.709 \\
2.626\end{array}$ & $\begin{array}{l}0.000 \\
0.009\end{array}$ \\
\hline
\end{tabular}

Based on the table above, the best regression model equation is obtained, which can be written mathematically as follows:

$$
\mathrm{Y} 2 \cdot 3=0,353 \mathrm{DAU}+0,609 \mathrm{DAK}
$$

By analyzing the table above, it is identified that the simultaneous influence of DAU and DAK is $99.7 \%$, and the remaining $0.3 \%$ is influenced by other factors not included in this model. After the assessment using goodness of fit test, it is identified that the value of $F$ is 33.595 at the significance level of 0.08 , which means that a simultaneous increase of development funding from DAU and DAK of IDR 1,000,000,000, the GRDP of secondary sector in Lanny Jaya will increase for IDR 33,595,000,000.

The result of partial analysis shows that the influences of DAU and DAK on the GRDP of secondary sector are $35.3 \%$ for DAU and $60.9 \%$ for DAK, and the remaining $0.38 \%$ is influenced by other factors not included in this model. Through the partial test in table 5.14 above, it is identified that the t value for DAU variable is 15.709 at the sig level of 0.00 , which means that an increase in development funding resource from DAU for IDR 1,000,000,000 will increase the GRDP of secondary sector in the regency of Lanny Jaya of IDR $15,709,000,000$.

Furthermore, the result of partial test also shows that the $t$ value for DAK variable is 2.626 at the sig level of 0.09 , which means that an increase in development funding resource from DAK for IDR $1,000,000,000$ will increase the GRDP of secondary sector in the regency of Lanny Jaya of IDR 2,626,000,000. Therefore, it can be concluded that, of the four developments funding resources analyzed in this study (PAD, DBH, DAU, and DAK) simultaneously influence the Gross Regional Domestic Product (GRDP) of secondary sector in the regency of Lanny Jaya. Partially, the variable that has the strongest influence on the GRDP of secondary sector in the regency of Lanny Jaya is DAU followed by DAK.

Analysis on the Influence of Development Funding Resources (PAD, DBH, DAU, and $D A K)$ on the Economy of Tertiary Sector. The process for analyzing tertiary sector is similar to the process of analyzing the previously discussed primary and secondary sector, in which, to identify the simultaneous influence of PAD, DBH, DAU, and DAK on the GRDP of tertiary sector in the regency of Lanny Jaya and to determine funding resource that has a dominant influence on the economy of secondary sector in the regency, a model should be selected first. The objectives of this selection are to calculate the simultaneous influence of independent variables (PAD, DBH, DAU, and DAK) and to determine independent variable that has a dominant influence on the dependent variable, which, in this case, is tertiary sector. 
In the process, a four-step regression analysis model using SPSS is conducted, from which the result is as follows.

Table 4 - Result of $\mathrm{F}$ test and $\mathrm{t}$ Test for Tertiary Sector

\begin{tabular}{|c|c|c|c|c|c|c|}
\hline \multirow{2}{*}{ Model } & \multicolumn{2}{|c|}{ Goodness of Fit test } & \multirow{2}{*}{ Funding Resources } & \multirow{2}{*}{ Coefficients } & \multicolumn{2}{|c|}{ Partial test } \\
\hline & $\mathrm{F}$ & Sig & & & $\mathrm{t}$ & Sig \\
\hline \multirow{5}{*}{1} & \multirow{5}{*}{14.644} & \multirow{5}{*}{0.026} & (Constant) & 112.450 & 0.787 & 0.489 \\
\hline & & & PAD & 0.732 & 0.358 & 0.744 \\
\hline & & & DBH & -0.988 & -0223 & 0.838 \\
\hline & & & DAU & 1.192 & 2.941 & 0.060 \\
\hline & & & DAK & 1.520 & 1.233 & 0.305 \\
\hline \multirow{4}{*}{2} & \multirow{4}{*}{25.588} & \multirow{4}{*}{0.005} & (Constant) & 85.359 & 1.300 & 0.263 \\
\hline & & & PAD & 0.574 & 0.343 & 0.947 \\
\hline & & & DAU & 1.115 & 6.033 & 0.004 \\
\hline & & & DAK & 1.586 & 1.518 & 0.204 \\
\hline \multirow{3}{*}{3} & \multirow{3}{*}{46.537} & \multirow{3}{*}{0.001} & (Constant) & 94.975 & 1.763 & 0.138 \\
\hline & & & DAU & 1.156 & 9.117 & 0.000 \\
\hline & & & DAK & 1.499 & 1.630 & 0.164 \\
\hline \multirow{2}{*}{4} & \multirow{2}{*}{70.854} & \multirow{2}{*}{0.000} & (Constant) & 147.748 & 3.037 & 0.023 \\
\hline & & & DAU & 1.190 & 8.418 & 0.000 \\
\hline
\end{tabular}

Data processing in SPSS 13.

- First Step:

The regression analysis in this step is also to analyze the simultaneous influence of development funding resource on the GRDP of primary sector. Thus, the four funding resources will also be included in the model analysis. Therefore, the developed regression model is appropriate with the output of the table above. The result of $F$ test and $t$ test for secondary sector is as follows:

$$
\mathrm{Y} 3.1=112.450+0,732 \mathrm{PAD}-0,988 \mathrm{DBH}+1.192 \mathrm{DAU}+1.520 \mathrm{DAK}
$$

Through the equation above, the constant is 112.450 , which informs that in the absence of development funding resource from PAD, DBH, DAU, and DAK, the GRDP of tertiary sector will be at the position of 112.450 or remains at IDR $-112,450,000,000$.

Based on the goodness of fit test in table 5.15 above, the significance value is 0.026 . This value is smaller than the predetermined significance level $(\alpha=5 \%)$, so it can be concluded that, in this model, development funding resource from PAD, DBH, DAU, and DAK simultaneously influence the GRDP of secondary sector in the regency of Lanny Jaya.

However, after a partial-wise parameter test (t test) is conducted, PAD and DBH are not significant because the sig values of their partial test are, respectively, 0.744 and 0.838 , which is greater than their $t$ values, which are, respectively, 0.358 and -0.223 . However, DAU and DAK are significant because the values of their partial test are, respectively, 0.060 and 0.305 , which are smaller than their $t$ values, which are, respectively, 2.941 and 1.233 . In addition, DAU is the variable with the strongest influence.

Of the two insignificant variables, $\mathrm{DBH}$ is the least significant because it has the highest significance value, which is 0.838 . Therefore, this variable must be excluded from the model of the next step.

- Second Step:

The regression equation, after the exclusion of $\mathrm{DBH}$ variable from the model, in this second step is as follows:

$$
\text { Y3.2 }=85.359+0,574 \text { PAD +1.115 DAU + 1.586 DAK }
$$

Based on the result of regression equation above, it is obtained that the constant is 85.359, which informs that in the absence of development funding resource from OwnSource Revenue (PAD), General Allocation Fund (DAU), and Special Allocation Fund (DAK), 
the Gross Regional Domestic Product (GRDP) in the regency of Lanny Jaya in tertiary sector will be at the position of 85.359 , or IDR $85,359,000,000$.

Referring to the result of goodness of fit test in the table above, the obtained significance value is 0.005 . This value is smaller than the predetermined significance level $(\alpha=5 \%)$. Therefore, it can be concluded that, in this model, development funding resource from three resources; they are DBH, DAU, and DAK simultaneously influence the GRDP of tertiary sector in the regency of Lanny Jaya.

However, after a partial-wise parameter test (t test) is conducted, PAD is not significant because the sig value of its partial test is 0.749 , which is greater than its $t$ value, which is 0.343. However, DAU and DAK are significant because the values of their partial test are, respectively, 0.004 and 0.204 , which are smaller than their $t$ values, which are, respectively, 6.033 and 1.518.

Because PAD variable is not significant, it must be excluded from the next step model.

- Third Step:

The regression equation in this third step is formed after excluding PAD variable from the model. The regression equation in this third step can be mathematically written as follows:

$$
\mathrm{Y} 3.3=94.975+1.157 \mathrm{DAU}+1.499 \mathrm{DAK}
$$

Based on the third step regression equation above, the constant is 94.975 , which informs that in the absence of development funding resource from DAU and DAK, the GRDP in the regency of Lanny Jaya in tertiary sector will only be at 94.975 , or IDR 94,975,000,000. This model also results in the statistical $F$ value of 46.537 with the significance level of 0.001 (sig approaching 0 ). In other words, DAU and DAK simultaneously influence the economy of tertiary sector in the regency of Lanny Jaya.

Using partial-wise parameter test ( $t$ test), it is identified that both variable of DAU and DAK partially influence the Gross Regional Domestic Product (GRDP) of tertiary sector in the regency of Lanny Jaya.

In addition, to identify which variable, between DAU and DAK, that is most significant in influencing the economy of tertiary sector in the regency of Lanny Jaya, partial-wise parameter test ( $t$ test) is conducted. Based on the $t$ test result, DAU is the most significant, so this variable is excluded from the model in the next analysis to get the best model.

- Fourth Step:

The equation in this fourth step is the best model in analyzing tertiary sector, which is obtained after excluding DAK from the model and can be mathematically written as follows:

$$
\mathrm{Y} 3.4=147.748+1.190 \mathrm{DAU}
$$

This third step regression model is the best model, which is using independent variable of DAU in the model. Based on this fourth step regression equation, the constant is 147.748 , which informs that in the absence of development funding resource from General Allocation Fund (DAU), the Gross Regional Domestic Product (GRDP) in the regency of Lanny Jaya in tertiary sector will only be at 147.748 , or IDR $147,748,000,000$. It is also obtained that the value in DAU variable is 1.190 , which means that an increase in development funding resource from DAK for IDR 1,000,000,000 will increase the GRDP of tertiary sector for IDR $1,190,000,000$.

\section{DISCUSSION OF RESULTS}

The Influence of Development Funding Resource on the Economy through Primary Sector. Based on the regression analysis, it is identified that, of four development funding resources in their relationship with the GRDP of the regency of Lanny Jaya, the following important findings are evident. 
Development funding resources through primary sector simultaneously do not influence the economic growth or GRDP of the regency of Lanny Jaya. This is identified from the significance level of 0.136 , which is smaller than the predetermined significance level $(\alpha=$ $5 \%)$. Therefore, hypothesis $1 \mathrm{a}$, which states that there is a simultaneous influence of development funding resources (PAD, DBH, DAU, and DAK) on the economic growth of primary sector is rejected. This result contradicts the opinion of Suparmoko M, et al. (2006) that fund allocation from the central government in forms of DAU, DAK, and DBH, together with PAD, plays an important role in implementing regional development, particularly that deals with agricultural economic growth, reformation of farmers' economic structure, and income equalization among economic sectors in one region or area.

Of the four variables that are analyzed, only two variables (i.e. DBH and DAU) that partially influence the economic growth or Gross Regional Domestic Product (GRDP) of the regency of Lanny Jaya, from which only DAU that has a significant influence, while the influence of $\mathrm{DBH}$ is insignificant. Therefore, hypothesis $1 \mathrm{~b}$, which states that there is a partial influence of development funding resource (PAD, DBH, DAU, and DAK) on the economic growth of primary sector, is also rejected. This finding contradicts the result of Sudirman (2013) that all development funding resources (PAD, DAU, DBH, and DAK) simultaneously and partially have a positive influence on the economic growth of all sectors in East Java. However, this finding supports the result of Prakosa (2004) that the predictability of DAU on reginal expenditures remains higher than the predictability of PAD and other development funding resources.

The significant influence of development funding resource from DAU on the GRDP or the economy of Lanny Jaya is probably because the development funding resource from General Allocation Fund (DAU) is actually higher than that from other sources (PAD, DAK, and $\mathrm{DBH}$ ) and because its allocation is mainly for primary sector, especially in agriculture and plantation. In addition, the high amount of DAU fund and its high influence on the economy indicate that the dependency of the regency of Lanny Jaya on the central government is still high. This finding supports the result of Arung Lamba (2013) that the role of central government in primary sector is still very much needed to increase farmers' production, i.e. $45.55 \%$, particularly in facility provision.

The Influence of Development Funding Resource on the Economy through Secondary Sector. There are several findings obtained from the regression analysis result regarding the influence of development funding resource on the economy of secondary sector in the regency of Lanny Jaya; they are as follows.

Development funding resources through primary sector simultaneously influence the economic growth or GRDP of the regency of Lanny Jaya. This is identified from the significance level of 0.008 , which is smaller than the predetermined significance level $(\alpha=$ $5 \%$ ). Therefore, hypothesis $2 a$, which states that there is a simultaneous influence of development funding resources (PAD, DBH, DAU, and DAK) on the economic growth of secondary sector, is accepted. This result supports the opinion of Ardiana Hutasoit (2014) that own-source revenue, together with balancing funds (DBH, DAU, and DAK), is essential for growth in all sectors in the province of North Sumatra, especially in secondary-sector occupations such as in processing industry, clean water provision, waste management and cleanliness, electricity provision, information and telecommunication, etc. This result also supports the opinion of Suparmoko M. et al. (2006) that fund allocation from the central government in forms of DAU, DAK, and $\mathrm{DBH}$, together with PAD, plays an important role in implementing regional development.

Of the four variables that are analyzed, only two variables (i.e. DBH and DAU) that partially influence the economic growth or Gross Regional Domestic Product (GRDP) of the regency of Lanny Jaya, from which, of the two influential variables, only DAU that has a significant influence. Therefore, hypothesis $2 b$, which states that there is a partial influence of development funding resource (PAD, DBH, DAU, and DAK) on the economic growth of secondary sector, is also rejected. This result contradicts the opinion of Ardiana Hutasoit (2014) that own-source revenue, together with balancing funds (DBH, DAU, and DAK), is essential for growth in all sectors in the province of North Sumatra, especially in secondary- 
sector occupations such as in processing industry, clean water provision, waste management and cleanliness, electricity provision, information and telecommunication, etc. However, this result supports the result of Soetojo (2012) that, different from primary sector, in secondary sector, of all sources of development expenditure fund in the province of West Sulawesi, the most influential ones are Revenue Sharing Fund and General Allocation Fund. This is probably due to the fact that both funding resources focus more on the development of secondary sector to accelerate industrial sector in the province.

The significant influence of development funding resource from general allocation fund and Revenue sharing fund on the Gross Regional Domestic Product or the economy of secondary sector in Lanny Jaya is because both development funding resources from DAU and $\mathrm{DBH}$ are high in amount compared to the other funding resources.

The Influence of Development Funding Resource on the Economy through Tertiary Sector. As in the influence of development funding resource on the economy through primary and secondary sector, there are also several important findings regarding the influence of development funding resource on the economy of secondary sector in the regency of Lanny Jaya; they are as follows.

Development funding resources simultaneously influence the economic growth of the regency of Lanny Jaya through primary sector. This is identified from the significance level of 0.026 , which is smaller than the predetermined significance level $(\alpha=5 \%)$.

Therefore, hypothesis $3 a$, which states that there is a simultaneous influence of development funding resources (PAD, DBH, DAU, and DAK) on the economic growth of tertiary sector, is accepted. This result supports the result of Davit Mandang et al. (2011) that the progress of business fields included in tertiary sector, such as trade, transportation, and various service fields, are inseparable from the role of reginal development funding resources (PAD, DBH, DAU, and DAK), both simultaneously and partially, which are really high in amount in the city of Surabaya. This result also supports the opinion of Ardiana Hutasoit (2014) that own-source revenue, together with balancing funds (DBH, DAU, and DAK), is essential for growth in all sectors in the province of North Sumatra, especially in secondary-sector occupations such as in processing industry, clean water provision, waste management and cleanliness, electricity provision, information and telecommunication, etc.

Of the four variables that are analyzed regarding their influence on the economic growth or Gross Regional Domestic Product (GRDP) of the regency of Lanny Jaya, only two variables (i.e. DAU and DAK) that partially influence the economic growth or Gross Regional Domestic Product (GRDP) of the regency of Lanny Jaya through tertiary sector. However, of the two influential variables, only DAU that has a significant influence.

Therefore, hypothesis $3 \mathrm{~b}$, which states that there is a partial influence of development funding resource (PAD, DBH, DAU, and DAK) on the economic growth of tertiary sector, is also rejected. This result contradicts the result of Evan Salakori et al (2010) that, although all development funding resources in Gorontalo are influential on the economic increase in secondary field, only two of them have a significant influence; they are General Allocation Fund and Special Allocation Fund, from which General Allocation Fund (DAU) has the strongest influence. The influence of other funding resources is insignificant, so they are ignored in this study. This is probably due to the fact that those two sources are the highest in amount. However, this result contradicts the result of Davit Mandang et al. (2011) that the progress of business fields included in tertiary sector, such as trade, transportation, and various service fields, are inseparable from the role of reginal development funding resources (PAD, DBH, DAU, and DAK), both simultaneously and partially, which are really high in amount in the city of Surabaya.

The significant influence of development funding resource from DAU on the GRDP or the economy through secondary sector in the regency of Lanny Jaya is probably because the development funding resources from DAU are higher in amount than that from other funding resources.

Finding of Research Results. Simultaneously, of the three sectors being examined (primary, secondary, and tertiary), only two of them are influenced by development funding resources; they are secondary and tertiary sectors, but primary sector is not influenced. 
This indicates that the government of Lanny Jaya does not help much and is not optimal in managing business in primary sector, e.g. agriculture, plantation, fishery, and mining, so the people have to traditionally do their business by themselves.

Partially, of the four funding resources being examined, the variable that has the biggest influence on each sector (primary, secondary, and tertiary) is DAU, followed by DAK and $\mathrm{DBH}$. Nevertheless, PAD does not have any influence. Balancing funds from the central government in forms of $\mathrm{DBH}, \mathrm{DAU}$, and DAK are influential with different magnitude, but $P A D$, which is the revenue generated originally from the region, is not influential. This indicates that the dependency of the government of Lanny Jaya on the central government is still high. This finding supports the opinion of Arung Lamba (2013) that the role of the central government is still very much needed in all sectors, especially primary sector, so that the economy in Papua can increase, particularly in facility provision.

\section{CONCLUSION}

1. The influence of development funding resource on the economic growth of primary sector in the regency of Lanny Jaya is as follows:

Simultaneously, there is no influence of development funding resources on the economic growth of primary sector in the regency of Lanny Jaya.

Partially, of the four development funding resources, only DAU that influences the economic growth of primary sector in the regency of Lanny Jaya.

This indicates that the government of Lanny Jaya does not help much and is not optimal in managing business in primary sector, e.g. agriculture, plantation, fishery, and mining, so the people have to traditionally do their business by themselves.

2. The influence of development funding resource on the economic growth of secondary sector in the regency of Lanny Jaya is as follows:

Simultaneously, development funding resources influence the economic growth of secondary sector in the regency of Lanny Jaya.

Partially, of the four development funding resources, only DAU and DBH that influence the economic growth of secondary sector in the regency of Lanny Jaya, but it is only DAU that is significant.

3. The influence of development funding resource on the economic growth of tertiary sector in the regency of Lanny Jaya is as follows:

Simultaneously, development funding resources influence the economic growth of tertiary sector in the regency of Lanny Jaya.

Partially, of the four development funding resources, only DAU and DAK that influence the economic growth of tertiary sector in the regency of Lanny Jaya, from which DAU has the strongest influence.

1. Because simultaneously primary sector is not influenced by development funding resource, this indicates the government of Lanny Jaya does not help much and is not optimal in managing business in primary sector, e.g. agriculture, plantation, fishery, and mining, so the people have to traditionally do their business by themselves.

2. Because partially all balancing funds from the central government in forms of $\mathrm{DBH}$, $D A U$, and DAK are influential with different magnitude and PAD, which is the revenue generated originally from the region, is not influential, the dependency of the government of Lanny Jaya on the central government is still high.

\section{REFERENCES}

1. Anita Alawiyah. 2011. http/anialawiyah.blogspot.co.id/2011/03/public-goods.html

2. Abigael Sundoyo. 2006. Ada Apa Dibalik Lahirnya Undang-Undang No.25 tahun 2004, Penerbit Erlangga. Jakarta

3. Ahmad Sujana. 2015. Pertumbuhan Ekonomi dan Perubahan Struktur Ekonomi, di Indonesia, PT Pustaka LP3ES Indonesia 
4. Amiir Sadikin (2011), Manfaat Dana-Dana Perimbangan (DBH, DAU dan DAK) dari Pusat, penerbit; PT Pustaka LP3ES Indonesia

5. Arung Lamba, 2015; Metode penelitian, Bahan Kuiah; Pascasarjana Universitas Cenderawasih.

6. Azise. 2013. Pengertian Karakteristik Public Goods dan Private Goods, http/aziseblogpot.co.id/2013/05/karakteristik-public-goods-dan-Private.htmi

7. Badan Perencanaan Pembangunan Daerah (BPPD) Lanny Jaya. 2008, 2009, 2010, 2011, 2013, 2014, 2015, Produk Domestik Regional Bruto Kabupaten Lanny Jaya, Menurut Lapangan Usaha.

8. Budiono, 1999, Teori Pertumbuhan Ekonomi, Edisi Kedua; BPFE Yogyakarta.

9. Dembrug Thomas F. 2005. Makro Ekonomi, Konsep teori dan Kebijakan Edisi Ketujuh. Penterjamah Karyaman Muchtar, Erlangga Jakarta.

10. Djarwanto PS, 2001, Mengenai beberapa Uji Statistik dalam Penelitian, Edisi Kedua, penerbit Liberty Yogyakarta.

11. Djoyohadikusumo, S. 1999. Perkembangan Pemikiran Ekonomi, Dasar Teori Ekonomi Pertumbuhan dan Ekonomi Pembangunan, PT Pustaka LP3ES Indonesia.

12. Ferry Prasetya. 2012. Teori Ekonomi Publik, Fakultas Ekonomi \& Bisnis Universitas Brawijaya-Malang.

13. Gujarati, D. 1999. Ekonometrika Dasar, Penerbit Erlangga, Jakarta.

14. Harun Hamrale. 2005. Analisis Ketersediaan Dana Pembangunan Daerah, BPFE, Yogyakarta.

15. Hasan Basri Umar. 2008. Kebijakan Fiskal, Pascasarjana Universitas Cenderawasih, Jayapura.

16. Hendarto Setiono. 2000. Perencanaan Pengembangan Wilayah Adalah suatu IImu (Edisi Revisi), Penerbit; Program Pascasarjana Universitas Hasanuddin, Ujung Pandang.

17. Husain Umar. 2008. Metode Penelitian Untuk Penyusunan Tesis Dan Disertasi, Penerbit PT Raja Grafindo Persada, Jakarta.

18. Junaidy Surya. 2013. Pengertian Barang Publik, http/junaidysurya blogpot.co.id/2013/08/pengertian-barang-publi.htmi.

19. Kerja Bappeda dan BPS kabupaten Lanny Jaya. 2008, 2009, 2010, 2011, 2013, 2014, 2015. Lanny Jaya Dalam Angka.

20. Mardiasmo. 2000. Otonomi Dan Manajemen Keuangan Daerah, Penerbit Andi Offset, Yogyakarta.

21. Mubyarto. 2001. Siklus Tujuh Tahun Ekonomi Indonesia, Universitas Gajamada, Yogyakarta

22. Poernomosidi Hadjisaroso. 2001. Perencanaan Pengembangan Wilayah (Konsep, Teori dan Aplikasi), Penerbit BKU Ilmu Ekonomi Dan Studi Pembangunan Pascasarjana Universitas Pajajaran, Bandung.

23. Raharjo Adisamita. 2007. Dasar-Dasar Ekonomi Wilayah, Fakultas Ekonomi Universitas Hasanuddin, Makassar.

24. Raharko Adisamita. 2010. Perencanaan Pengembangan Wilayah (Konsep Teori), Penerbit Graha IImu, Yogyakarta.

25. Raharjo Adisamita. 2001. Pembiayaan Pembangunan Daerah, Fakultas Ekonomi Universitas Hasanuddin, Makassar.

26. Raharjo Adisamita. 2007. Produk Domestik Ragional Bruto (PDRB), Penerbit Graha IImu, Yogyakarta.

27. Raharjo Adisamita. 1996. Pedoman perhitungan PDRB Kabupaten, Penerbit Badan Pusat Statistik, Jakarta.

28. Robinson Taringan. 2010. Perencanaan Pengembangan Ekonomi Regional (Teori dan Aplikasi), Penerbit Bumi Aksara, Jakarta

29. Republik Indonesia. 1999. Undang-Undang Nomor 25 Tahun 1999 tentang Perimbangan Keuangan Antara pusat Dan Daerah, Penerbit Citra Umbara; Bandung.

30. Republik Indonesia. 2001. Undang-Undang Nomor 21 Tahun 2001 Tentang Otonomi Khusus Provinsi Papua; Penerbit Citra Umbara Bandung 
31. Republik Indonesia. 2004. Undang-Undang Nomor 33 Tahun 2004 tentang Perimbangan Keuangan Antara pusat Dan Daerah, Penerbit Citra Umbara; Bandung.

32. Sadono Sukirno. 1994. Teori Pengantar Ekonomi Mikro, Edisi Keiga, Penerbit Raja Grafindo Persada, Jakarta

33. Soekarwo. 2003. Berbagai Permasalahan Keuangan Daerah, Cetakan Pertama. Airlangga University Press, Surabaya

34. Sumodininngrat. 1998. Membangun Perekonomian rakyat, Seri Ekonomi Pembangunan, Penerbit Pustaka Pelajar Dan IDEA; Jogyakarta

35. Suparmoko M. 2006. Produk Domistik Ragional Bruto (PDRB) Hijau, Edisi Pertama; Penerbit Fakultas Ekonomi UGM, Jogyakarta

36. Suwarno. 2006. Analisis Faktor-Faktor Yang mempengaruhi Peningkatan Pndapatan Daerah Sebagai Sumber Pembangunan Daerah; Studi Kasus Kota Surabaya, Tesis S-2 Pascasarjana Universitas Brawijaya, Malang

37. Todaro, MP. Ekonomic Development In The Tird World Sixh Edition, Logman, London

38. Tri Sungkono. 2010. Fungsi Dan Manfaat Dana Perimbangan ( Dana Bagi Hasil, Dana Alokasi Umum, dan Dana Alokasi Khusus) Bagi suatu Daerah, Penerbit Pustaka Pelajar Dan IDEA; Jogyakarta.

39. Yani, Ahmad. 2008. Hubungan Keuangan Antara Pemerintah Pusat Dan Daerah Di Indonesia , Seri Keuangan Publik, Edisi Revisi, Cetakan Pertama. PT Raja Grafindo Perdasa, Jakarta

40. Wikipidia. 2014. Bahasa Indonesia htpps://id.wikipedaOrg/wiki/Barang-Publik. 